\title{
Chromosome 11 allele loss in sporadic insulinoma
}

\author{
P Patel, S O'Rahilly, V Buckle, Y Nakamura, R C Turner, J S Wainscoat
}

\begin{abstract}
DNA was extracted from tissue samples of three unrelated cases of insulinoma. Chromosome 11 allele loss was investigated using several chromosome 11 specific probes which detect restriction fragment length polymorphisms. In one case, which proved informative for many of the chromosome 11 markers, allele loss was shown on both $11 \mathrm{p}$ and 11q. This finding is of considerable interest as the allele loss closely corresponds to that recently reported in insulinomas occurring in the familial multiple endocrine neoplasia type 1 (MEN-1) syndrome.
\end{abstract}

There is now considerable evidence supporting the notion that some malignant tumours are generated by recessive mutations. ${ }^{1}$ The most compelling evidence is found in the case of retinoblastoma in which homozygosity or hemizygosity of a recessive mutant allele results in the loss of the normal gene product. ${ }^{2}$ This work has substantiated the proposal originally made by Knudson ${ }^{3}$ that sporadic and inherited forms of a particular tumour may result from mutations in the same gene. There is now also suggestive evidence for a similar model in several other tumours. ${ }^{4}$

Recently the gene for the multiple endocrine neoplasia type 1 syndrome (MEN-1) has been localised to chromosome 11 by family studies. ${ }^{5}$ The comparison of constitutional and tumour tissue genotypes of insulinomas removed from two brothers with MEN-1 showed a loss of alleles from chromosome 11 in both cases, and it was postulated that oncogenesis in these cases involved an unmasking of a recessive mutation at the MEN-1 locus. We report the first comparable analysis, as far as we know, of chromosome 11 allele loss in three unrelated cases of sporadic insulinoma.

\section{Methods}

Tissue samples were obtained fresh from three cases of sporadic insulinoma removed at surgery. Samples of peripheral blood were also obtained. DNA samples were extracted from blood and tissue according to standard methods, ${ }^{6}$ digested with appropriate restriction endonucleases, and size fractionated by electrophoresis through $1 \%$ agarose gels. The digests of tumour DNA were electrophoresed in tracks adjacent to digests of the corresponding constitutional DNA from blood. DNA was transferred to nylon membranes (Hybond-N, Amersham UK) by Southern blotting and hybridised to DNA probes labelled with ${ }^{32} \mathrm{P}$-deoxycytidine triphosphate by the random hexanucleotide primer method. ${ }^{7}$ After hybridisation filters were washed under stringent conditions and autoradiographed at $-70^{\circ} \mathrm{C}$ using Fuji $x$ ray film.

\section{Results}

Allele losses were shown by comparing the intensities of alleles from the two homologous chromosomes on Southern blots between tumour DNA and constitutional DNA extracted from peripheral blood. A considerable reduction in the intensity of one allele band in the tumour DNA indicates a chromosomal loss at that locus (figure); the analysis is only informative at loci which are polymorphic in a particular patient. The faint bands remaining are presumably due to an admixture of normal cells. The results of such an analysis using probes from a series of loci on chromosome 11 and several other randomly chosen loci on other chromosomes are shown in the table. Case 1 shows no allele loss at three loci on the short arm of chromosome 11 (11p) and is uninformative at other loci on chromosome 11 . Case 2 is uninformative at most loci on chromosome 11 but does show loss with the probe MCT128.1 which is sited on 11q. Case 3 shows loss at all the chromosome 11 loci for which the analysis is informative, including several loci on $11 \mathrm{p}$ and one on 11q. None of the patients showed any allele loss with the randomly chosen probes on chromosomes other than chromosome 11.

\section{Discussion}

We examined the DNA of three cases of sporadic insulinoma for chromosome 11 allele loss. One case (1) did not have demonstrable allele loss and a second patient (2) was largely

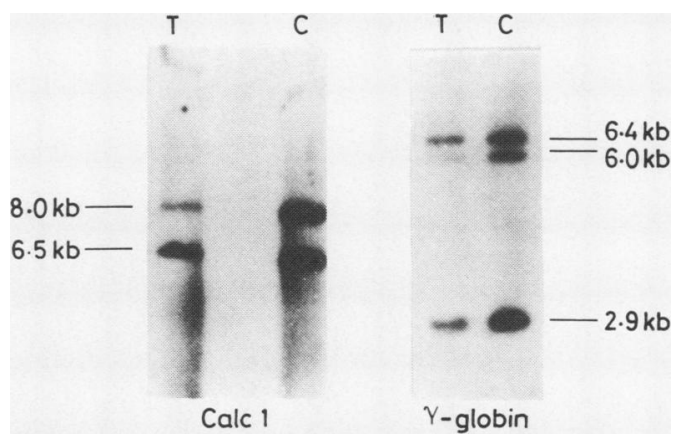

Autoradiograms showing allele loss at the calcitonin 7 locus (Calc 1) and $\gamma$-globin locus. Tumour DNA (T) has a loss of the 8.0 kilobase Calc 1 allele and a loss of the 6.0 kilobase globin allele compared with constitutional $D N A(C)$. 
Analysis of allele loss in three cases of insulinoma

\begin{tabular}{|c|c|c|c|c|}
\hline Locus & Chromosomal assignment & Case 1 & Case 2 & Case 3 \\
\hline $\begin{array}{l}\text { CAT } \\
\text { PTH } \\
\text { CALC1 } \\
\text { 'Globin } \\
\text { HRAS1 } \\
\text { INS }\end{array}$ & $\begin{array}{l}11 \mathrm{p} 13 \\
11 \mathrm{pter}-\mathrm{p} 15.4 \\
11 \mathrm{p} 15.4 \\
11 \mathrm{p} 15.5 \\
11 \mathrm{p} 15.5 \\
11 \mathrm{p} 15.5\end{array}$ & $\begin{array}{l}\mathbf{U} \\
\mathbf{U} \\
\mathbf{U} \\
\mathbf{N} \\
\mathbf{N} \\
\mathbf{N}\end{array}$ & $\begin{array}{l}\mathrm{ND} \\
\mathrm{U} \\
\mathrm{U} \\
\mathrm{U} \\
\mathrm{U} \\
\mathrm{U}\end{array}$ & $\begin{array}{l}\text { U } \\
\text { U } \\
\text { Loss } \\
\text { Loss } \\
\text { Loss } \\
\text { U }\end{array}$ \\
\hline $\begin{array}{l}\text { ApoA1 } \\
\text { pHB118P2 } \\
\text { MCT128.1 }\end{array}$ & $\begin{array}{l}11 \mathrm{q} 23-\mathrm{qter} \\
11 \mathrm{q} \\
11 \mathrm{q}\end{array}$ & $\begin{array}{l}\mathrm{U} \\
\mathrm{U} \\
\mathrm{N}\end{array}$ & $\begin{array}{l}\mathrm{U} \\
\mathrm{U} \\
\text { Loss }\end{array}$ & $\begin{array}{l}\text { U } \\
\text { Loss } \\
\text { U }\end{array}$ \\
\hline $\begin{array}{l}\text { plambda MS1 } \\
\text { plambda MS8 } \\
\text { plambda MS31 } \\
\text { METD } \\
\text { METH } \\
\text { plambda g3 } \\
\text { palpha 3'HVR }\end{array}$ & $\begin{array}{l}1 \mathrm{p} 35-\mathrm{p} 33 \\
5 \\
7 \mathrm{pter}-\mathrm{q} 22 \\
7 \mathrm{q} 22.32 \\
7 \mathrm{q} 22.32 \\
7 \mathrm{q} 36-\mathrm{qter} \\
16 \mathrm{p} 13\end{array}$ & $\begin{array}{l}\mathbf{N} \\
\mathbf{N} \\
\mathbf{N} \\
\mathbf{U} \\
\mathbf{N} \\
\mathbf{N} \\
\mathbf{N}\end{array}$ & $\begin{array}{l}\mathbf{N} \\
\mathbf{N} \\
\mathbf{N} \\
\mathbf{N} \\
\mathbf{N} \\
\mathbf{N} \\
\mathbf{N}\end{array}$ & $\begin{array}{l}\text { ND } \\
\text { ND } \\
\text { U } \\
\mathbf{U} \\
\mathbf{N} \\
\mathbf{N} \\
\mathbf{N}\end{array}$ \\
\hline
\end{tabular}

Loss = loss of one allele; $\mathrm{N}=$ no allele loss; $\mathrm{U}=$ uninformative - homozygous for the RFLP; $\mathrm{ND}=$ not done.

uninformative, although an allele loss on the long arm of chromosome 11 was shown with probe MCT128.1. The third case (3), however, showed loss of chromosome 11 alleles corresponding to that described in the two patients with MEN-1, both of which showed loss at all loci on $11 \mathrm{p}$ and $11 \mathrm{q}$. This is a very interesting finding as several other tumours including breast cancer, ${ }^{8}$ bladder cancer, ${ }^{9}$ and Wilms' tumour ${ }^{10}$ have shown losses of 11 p sequences. It is possible that both the reported cases and the present insulinoma cases have monosomy 11 ; we attempted a cytogenetic analysis in case 3 , but unfortunately this was unsuccessful.

The association between familial and sporadic cancers is of great interest to mechanisms of carcinogenesis and the evidence presented here suggests a close relation in the genetic basis between the familial and sporadic forms of insulinoma. Further studies of insulinomas should resolve the nature of the chromosome 11 deletion and its relation to that found in the familial cases.
We gratefully acknowledge Drs A Jeffreys, D R Higgs, G N Hendy, R Gravel and ICI Diagnostics for the generous gifts of probes.

1 Hanson MF, Cavenee WK. Tumor suppressors: recessive mutations that lead to cancer. Cell 1988;53:172-3.

2 'Cavanee WK, Dryja TP, Phillips RA, et al. Expression of recessive alleles by chromosomal mechanisms in retinoblastoma. Nature 1983;305:779-84.

3 Knudson AG. Mutation and cancer: statistical study of retinoblastoma. Proc Natl Acad Sci USA 1971;68:820-3.

4 Knudson AG. Hereditary cancers: clues to mechanisms of carcinogenesis. Br J Cancer 1989;59:661-5.

5 Larsson C, Skogseid B, Oberg K, et al. Multiple endocrine neoplasia Type 1 gene maps to chromosome 11 and is lost in insulinoma. Nature 1988;332:85-7.

6 Maniatis T, Fritsch EF, Sambrook J. Molecular cloning. A laboratory manual. New York: Cold Spring Harbor Laboratory, 1982.

7 Fienberg AP, Vogelstein B. A technique for radiolabelling DNA restriction endonuclease fragments to high specific activity. Anal Biochem 1983;132:6-13.

8 Ali IU, Lidereau R, Theillet C, Callahan R. Reduction to homzygosity of genes on chromosome 11 in human neoplasia. Science 1987;238:185-8.

9 Fearon ER, Feinberg AP, Hamilton SR, Vogelstein B. Loss of genes on the short arm of chromosome 11 in bladder of genes on the short arm of chrom

10 Koufos A, Hansen MF, Copeland NG, et al. Loss of heterozygosity in three embryonal tumours suggests a common pathogenetic mechanism. Nature 1985;316: $330-4$. 